\title{
Intimate Partner Violence in China: National Prevalence, Risk Factors and Associated Health Problems
}

\section{By William L. \\ Parish, Tianfu \\ Wang, EdwardO. \\ Laumann, \\ Suiming Pan and \\ YeLuo \\ William L. Parish is professor of sociology, University of Chicago, \\ Chicago, IL, USA. \\ Tianfu Wang is \\ lecturer in sociology, \\ Qinqhua University, \\ Beijing. Edward O. \\ Laumann is professor of sociology, Universi- \\ ty of Chicago. Ye Luo is research analyst, the \\ Population Research \\ Center, National \\ Opinion Research \\ Center, Chicago. \\ Suiming Pan is \\ professor of sociology, \\ Renmin University,} Beijing.

\begin{abstract}
CONTEXT: Intimate partner violence has been studied in many developed and developing countries. China remains one of the few large societies for which the prevalence and correlates of intimate partner violence are unknown.
\end{abstract}

METHODS: Data from a nationally representative sample of women and men aged 20-64 with a spouse or other steady partner provide estimates of intimate partner violence in China. Binomial and multinomial logistic regression analyses adjusted for sample design examine risk factors and negative outcomes associated with partner violence.

RESULTS: Altogether, 34\% of women and 18\% of men had ever been hit during their current relationship; the prevalence of hitting resulting in bleeding, bruises, swelling, or severe pain and injuries was $12 \%$ for women and $5 \%$ for men. Significant risk factors for partner violence included sexual jealousy, patriarchal beliefs, low female contribution to household income, low male socioeconomic status, alcohol consumption and residence in regions other than the South and Southeast. Severe hitting was a significant risk factor for self-reported adverse general and sexual health outcomes, including sexual dysfunction, sexual dissatisfaction and unwanted sex.

CONCLUSIONS: As in other societies, intimate partner violence in China is common and is correlated with adverse general and sexual health outcomes.

International Family Planning Perspectives, 2004, 30(4):174-181
Research on intimate partner violence in developed and developing countries suggest that intimate partner violence occurs in all societies. ${ }^{1}$ Among 28 studies based on national population-based probability samples, the median prevalence of lifetime partner violence against women is $21 \%$; a much higher prevalence is reported for countries such as Egypt (34\%), New Zealand (35\%) and Colombia (40\%). In 10 national and regional studies, the median prevalence of hitting resulting in physical injury is $11 \%{ }^{2}$

Known risk factors of intimate partner violence include young age, poverty, low social status, women's disempowerment, stress in daily life, alcohol consumption and jealousy. ${ }^{3}$ Furthermore, intimate partner violence is associated with negative physical and mental health sequelae (e.g., depression, low self-esteem, alcohol abuse) and, potentially, sexual and reproductive health issues. ${ }^{4}$ The pathways for such outcomes include lingering physical and emotional trauma that exacerbates continuing physical health, mental health and gynecological problems. ${ }^{5}$ In addition, threats of violence may reduce individuals' ability to practice safe sex, increasing their risk of sexually transmitted infections (STIs).

Much remains to be understood about the total set of possible negative sexual and reproductive health outcomes associated with intimate partner violence, especially in developing countries such as China. ${ }^{6}$ Since the mid-1990s, the subject has received more attention in China, with sev-

*For details, see <http://www.src.uchicago.edu/prc/chfls.php >. eral studies suggesting that $20-30 \%$ of Chinese women have been hit by their spouse ${ }^{7}$ however, none of these studies provide national estimates. This study supplies the first national analysis of intimate partner violence in China, including prevalence by perpetrator and severity; risk factors; and general, sexual and reproductive health correlates of violence among men and women.

\section{METHODS}

\section{Data}

We used data from the 1999-2000 Chinese Health and Family Life Survey, which included a nationally representative sample of the adult population aged 20-64. Following standard procedures for complex samples, the probabilistic sample was drawn from 14 strata and 48 primary sampling units (counties and city districts), with probabilities of selection proportional to population size at each of the four sampling steps down to the individual. ${ }^{8 *}$ Participants responded to an hour-long computer-based interview; most interviewers were trained social workers and researchers, and were of the same sex as the respondents they interviewed. To protect respondents' privacy, interviews usually took place in a private hotel room or in a meeting facility. Respondents answered most of the questions in the study when the interviewer was in control of the computer, although questions about sexual behavior were answered while the respondent controlled the computer. At the completion of the interview, participants also gave a urine sample, which was tested for chlamydia. 
Of 5,000 individuals initially sampled, 3,806 completed the interview and provided valid data for analyses-for a response rate of $76 \%$. Of those, we used reports from the 1,665 women and 1,658 men who had a steady sexual partner at the time of interview. We defined a steady partner as someone with whom the respondent was currently involved in a sexual relationship of at least a month's duration; for the vast majority (98\%), the steady partner was a spouse.

\section{Dependent Variables}

Respondents were asked whether their partner had ever hit them, not including hitting in a joking or playful way.* Conversely, participants were asked if they had ever hit their partner. The possible responses for both questions were "yes, in last 12 months," "yes, but more than 12 months ago" and "never." We combined the first two categories to analyze any hitting during the lifetime of the current relationship. Respondents who had ever been hit by their partner were asked, "Did your partner ever hit you hard?" This was defined as an attack resulting in bleeding, a bruise, swelling or severe pain and injury; respondents could answer yes or no.

\section{Independent Variables}

Respondents were asked questions about social and demographic characteristics, beliefs and attitudes considered risk factors for intimate partner violence, with an emphasis on sexual jealousy, patriarchal values, bargaining and dependency, and stress and lifestyle. Sexual jealousy is thought to be an important factor involved in partner violence. ${ }^{9}$ In the questionnaire, respondents were asked "Have you ever felt insecure, "green eyed" ( $c h i c u$ ) or even jealous about your partner?" Conversely, respondents reported whether their partners had ever felt this way about them. The possible answers for both questions were "often," "occasionally," "rarely" and "never"; we condensed the first two responses into yes and the last two to no.

Another factor associated with partner violence in previous studies is patriarchal values that legitimate men's control of women. ${ }^{10}$ In the questionnaire, this type of attitude was examined with the question "Women say that in sex, men should be proactive and take the lead while women should be cooperative and acquiescent. What is your opinion?" Respondents could answer "women should not be proactive" or "women should be proactive."

Women's disempowerment can inhibit women from leaving or resisting abusive relationships. Women's increasing income diminishes violence, but only up to a point. When a woman earns much of the family income, her partner may lash out in frustration-suggesting a possible curvilinear relationship between women's income and hitting. ${ }^{11}$ In this study, disempowerment was measured by whether the female partner was more than two years younger than the male and by whether she earned 30\% or less of the couple's joint income. To investigate the aforementioned violence that can occur when a woman earns much of the couple's income, we also included whether the women earned more than
$45 \%$ of the couple's income. Most hitting occurs when spouses are young. ${ }^{12}$ Thus, the most relevant income figure, particularly for older couples who are out of the labor force, is not current income but an estimate of what each partner would have been earning at an earlier age. We determined this estimate from regression equations (separate for men and women) that included education, occupation, geographic region and work status. We then used the results to estimate partners' relative income, and expressed it as the proportion of income contributed by the woman.

Low education, menial occupation and low income have previously been shown to be risk factors for partner violence, with some research suggesting that these elements create more stress between spouses-particularly when the man is of low socioeconomic status. ${ }^{13}$ A woman may also be at higher risk if she or her partner uses alcohol. ${ }^{14}$ In this study, male socioeconomic status combines the man's education (six-point scale) and occupation (nine-point scale) in a factor analysis. This scale was divided into three groups, with most of the men clustered in the middle group.

We included several other factors likely to influence hitting. As our outcome measure is any hitting during the relationship, it is likely that hitting is associated with relationship duration-with the greatest increase being in the early years when partners are younger. ${ }^{15}$ We also control for region and urban location. The South and Southeast coastal region, which extends from Shanghai to Guangzhou, includes provinces with a booming economy and multiple foreign influences. The North and Northeast region includes both China's heavy-industry rust belt and sites in and around the capital of Beijing. The "inland" region includes central and western China. We defined urban sites as locales with less than $15 \%$ of the labor force in farming.

In existing research, partners often disagree on the level of hitting. ${ }^{16}$ For the sake of simplicity, we included "male respondent" to take into account consistent under- or overreporting by either partner. We conducted separate analyses (not reported here) for each gender and for gender interactions with each risk factor. In various places, we note differences between the reported and unreported results.

\section{Negative Outcomes}

To examine the negative outcomes associated with intimate partner violence, respondents were asked questions about their general happiness and health, and their sexual health and satisfaction. We included 15 items that examined respondents' self-reports of unhappiness with life or poor health in the past year; mental distress during the last three months; having had at least one problem during sex that lasted two months or more during the past year (i.e., lack of interest in sex, inability to achieve orgasm, inability to find pleasure in sex, performance anxiety in sex, erectile dysfunction, premature ejaculation, inadequate lubrication or pain during sex); physical or emotional dissatisfaction

* Literally, the question was whether their partner had "moved his/her hand/foot to hit (da) you," which could include slapping, hitting, kicking or other types of beating. 


\begin{tabular}{|c|c|c|c|c|c|c|c|}
\hline \multirow[t]{2}{*}{ Characteristic } & \multirow{2}{*}{$\begin{array}{l}\% \\
(\mathrm{~N}=3,323)\end{array}$} & \multicolumn{3}{|l|}{$\%$} & \multicolumn{3}{|c|}{ Relative risk ratios } \\
\hline & & $\begin{array}{l}\text { Male-on- } \\
\text { female }\end{array}$ & Mutual & $\begin{array}{l}\text { Female- } \\
\text { on-male }\end{array}$ & $\begin{array}{l}\text { Male-on- } \\
\text { female }\end{array}$ & Mutual & $\begin{array}{l}\text { Female-on- } \\
\text { male }\end{array}$ \\
\hline All & 100 & 19.0 & 15.0 & 3.3 & na & na & na \\
\hline \multicolumn{8}{|l|}{ Gender } \\
\hline Female (ref) & 50 & 15.4 & 15.2 & 3.5 & 1.00 & 1.00 & 1.00 \\
\hline Male & 50 & 22.6 & 14.8 & 3.0 & $1.13(0.38-3.32)$ & $1.08(0.63-1.85)$ & $0.61(0.32-1.14)$ \\
\hline \multicolumn{8}{|l|}{ Region } \\
\hline South/Southeast coast (ref) & 11 & 11.2 & 8.1 & 2.6 & 1.00 & 1.00 & 1.00 \\
\hline North/Northeast & 24 & $14.4^{*}$ & $13.9^{*}$ & $4.4^{*}$ & $1.31(0.87-1.97)$ & $2.18(1.54-3.11)^{*}$ & $2.48(1.43-4.30)^{*}$ \\
\hline Interior & 65 & $22.0^{*}$ & $16.5^{*}$ & 2.9 & $2.61(1.51-4.51)^{*}$ & $3.40(1.76-6.60)^{*}$ & $2.22(0.94-5.26)$ \\
\hline \multicolumn{8}{|l|}{ Residence } \\
\hline Urban (ref) & 29 & 13.6 & 12.6 & 3.9 & 1.00 & 1.00 & 1.00 \\
\hline Rural & 71 & $21.1^{*}$ & 15.9 & 3.0 & $0.86(0.55-1.33)$ & $0.85(0.50-1.45)$ & $1.03(0.55-1.91)$ \\
\hline \multicolumn{8}{|l|}{ Relationship duration } \\
\hline $0-5$ (ref) & 18 & 10.7 & 12.4 & 4.9 & 1.00 & 1.00 & 1.00 \\
\hline $6-15$ & 35 & $20.1^{*}$ & $21.4^{*}$ & 4.7 & $2.54(1.07-6.01)^{*}$ & $2.13(1.17-3.87)^{*}$ & $1.05(0.32-3.52)$ \\
\hline$\geq 16$ & 47 & $21.3^{*}$ & 11.2 & 1.6 & $2.89(0.84-9.98)$ & $1.10(0.44-2.75)$ & $0.43(0.09-2.09)$ \\
\hline \multicolumn{8}{|l|}{ Age difference } \\
\hline Male $\leq 2$ yrs. older (ref) & 69 & 20.7 & 15.1 & 3.9 & 1.00 & 1.00 & 1.00 \\
\hline Male 3-11 yrs. older & 31 & $15.1^{*}$ & 14.8 & 1.8 & $0.71(0.50-0.99)^{*}$ & $0.99(0.45-2.16)$ & $0.45(0.20-1.03)$ \\
\hline \multicolumn{8}{|c|}{ Man's socioeconomic status } \\
\hline High (ref) & 16 & 12.5 & 13.1 & 3.7 & 1.00 & 1.00 & 1.00 \\
\hline Middle & 59 & $18.1^{*}$ & 12.4 & 4.0 & $2.02(1.39-2.93)^{*}$ & $1.21(0.71-2.06)$ & $1.64(0.81-3.10)$ \\
\hline Low & 24 & $25.5^{*}$ & $22.4^{*}$ & 1.2 & $3.65(2.10-6.34)^{*}$ & $4.22(2.42-7.37)^{*}$ & $1.71(0.26-11.10)$ \\
\hline \multicolumn{8}{|c|}{ Woman's contribution to income } \\
\hline $0-30 \%$ & 14 & 21.9 & 12.0 & 4.1 & $1.56(1.01-2.42)^{*}$ & $1.11(0.65-1.89)$ & $1.45(0.69-3.08)$ \\
\hline $31-45 \%$ (ref) & 59 & 16.8 & 13.7 & 3.9 & 1.00 & 1.00 & 1.00 \\
\hline $46-100 \%$ & 27 & 22.3 & 19.3 & 1.3 & $1.32(0.58-3.01)$ & $1.08(0.66-1.78)$ & $0.31(0.10-0.94)^{*}$ \\
\hline \multicolumn{8}{|l|}{ Alcohol consumption } \\
\hline None (ref) & 78 & 15.1 & 12.7 & 2.4 & 1.00 & 1.00 & 1.00 \\
\hline Any & 22 & 16.4 & 23.8 & $7.3^{*}$ & $1.68(1.01-2.78)^{*}$ & $2.29(0.81-6.44)$ & $2.85(1.13-7.23)^{*}$ \\
\hline \multicolumn{8}{|l|}{ Male } \\
\hline Never inebriated (ref) & 57 & 16.4 & 12.3 & 2.5 & 1.00 & 1.00 & 1.00 \\
\hline Inebriated in last year & 43 & $30.7^{*}$ & $18.0^{*}$ & 3.6 & $3.09(1.56-6.12)^{*}$ & $1.97(1.00-3.90)$ & $1.43(0.57-3.56)$ \\
\hline \multicolumn{8}{|l|}{ Sexual jealousy } \\
\hline None (ref) & 78 & 17.8 & 10.9 & 2.4 & 1.00 & 1.00 & 1.00 \\
\hline Male & 5 & 11.7 & $35.9^{*}$ & $11.1^{*}$ & $1.48(0.65-3.34)$ & $6.47(3.57-11.71)^{*}$ & * $5.68(2.40-13.44)^{*}$ \\
\hline Female & 9 & $29.5^{*}$ & $25.4^{*}$ & $6.3^{*}$ & $4.42(2.54-7.69)^{*}$ & $6.10(4.22-8.84)^{*}$ & $4.23(1.17-15.24)^{*}$ \\
\hline Both & 8 & $22.9^{*}$ & $29.7^{*}$ & $3.8^{*}$ & $3.54(2.29-5.47)^{*}$ & $6.27(2.58-15.22)^{*}$ & * $1.95(0.77-4.91)$ \\
\hline \multicolumn{8}{|l|}{$\begin{array}{l}\text { Belief that men lead in sex } \\
\text { Male }\end{array}$} \\
\hline No (ref) & 74 & 20.4 & 14.6 & 3.0 & 1.00 & 1.00 & 1.00 \\
\hline Yes & 26 & 28.9 & 15.4 & 3.1 & $1.56(1.00-2.46)$ & $1.30(0.66-2.58)$ & $1.50(0.20-11.52)$ \\
\hline \multicolumn{8}{|l|}{ Female } \\
\hline No (ref) & 50 & 11.6 & 14.7 & 6.3 & 1.00 & 1.00 & 1.00 \\
\hline Yes & 50 & $19.2^{*}$ & 15.7 & 0.7 & $1.53(0.58-4.01)$ & $1.32(0.63-2.78)$ & $0.16(0.04-0.66)^{*}$ \\
\hline Total & 100 & na & na & na & na & na & na \\
\hline
\end{tabular}

*Significantly different from the referent at $\mathrm{p}<.05$. Notes: na=not applicable. $\mathrm{N}$ is unweighted. All results are weighted. Absence of hitting is the referent outcome for both the percentages and the multinomial logistic regression.

with sex with spouse during the past year; absence of kissing during sex; absence of intimacy or foreplay during sex; ever having had unwanted sex with spouse; having participated in unwanted acts during sex with spouse during the past year; partner's extramarital sex (suspected or proven); having had at least one genitourinary symptom in the past year (i.e., burning pain while urinating; genital lesion, blister or sore; genital discharge of unusual color or odor; warts; irregular vaginal bleeding or lower abdominal pain); ever having had an STI; having a positive urine test for chlamydia; and giving fewer than three correct answers on six knowledge questions about HIV/AIDS. 
The analysis of negative outcomes examines the bivariate and multivariate correlates of hitting and severe hitting. The multivariate analysis controls for possible confounding factors, including for all outcomes 10-year age-group, urban residence and geographic region of the respondent. Moreover, in stepwise regressions that allowed variables to enter the equation when they had even a very modest statistical significance ( $p<.20)$, equations could include education, household income and menopause for women. Also, in the analysis of unhappiness with life, mental distress, poor health, marital status and presence of preschool children could enter the stepwise equations.

\section{Analysis}

We weighted results in our analyses, first using population weights that adjusted for the intentional oversampling of coastal and urban settings. After comparison of the resulting age distribution to census results for 2000, we adjusted weights by age to compensate for the smaller number of usable interviews of 20-29-year-olds and 50-64-yearolds. With these adjustments, the percentage distributions by age, occupation, urban residence and education closely parallel those in the national census. Using STATA 8.0, we adjusted standard errors in our logistic regression analyses for sample stratification (sampling strata independently) and clustering (sampling individuals within each of 48 primary sampling units). ${ }^{17}$

\section{RESULTS}

The sample was equally divided between men and women (Table 1). After the sample was weighted, most respondents lived in the interior part of the country and in a rural area. Nearly half (47\%) had been with their current partner for at least 16 years, and more than two-thirds reported that the age difference between themselves and their partner did not exceed two years. Twenty-four percent described the male in the relationship as being of low socioeconomic status, and $27 \%$ reported that the female contributed more than $45 \%$ of the couple's income. The level of any alcohol use was low among women (22\%) and high among men (75\%--not shown); $43 \%$ of men reported having been drunk in the past year. Seventy-eight percent of respondents reported that neither they nor their partner had felt sexual jealousy or had done so only rarely; $5 \%$ reported that the male had often or sometimes felt jealous, $9 \%$ the female and $8 \%$ both. Some $74 \%$ of men believed that men should lead during sex, compared with 50\% of women.

Overall, 19\% of respondents reported male-on-female violence within their relationship, and 3\% reported femaleon-male violence (Table 1). Another 15\% had experienced mutual hitting, and thus a total of $34 \%$ had experienced maleon-female intimate partner violence and 18\% had experienced female-on-male intimate partner violence. When the data were separated by gender, $15 \%$ of women and 3\% of men reported having ever been hit by their partner; an additional 15\% of each reported mutual hitting. Twelve percent of women and $5 \%$ of men had experienced hard hitting (not shown).
An additional analysis provided more descriptive detail. When male-on-female hitting and mutual hitting were combined, $37 \%$ of men reported that the woman in the relationship had ever been hit, compared with $31 \%$ of women. The reason for this gap might be that the sample was not made up of couples, so that males and females were not reporting on a shared history. Nevertheless, when we used an equation to control for possible confounding factors (e.g., age of woman, region, rural residence, duration of the relationship, man's socioeconomic status and woman's income share), men remained statistically more likely than women to report that the woman in the relationship had experienced violence (odds ratio, 1.5-not shown).

In bivariable analyses, partner violence was associated with most of the explanatory measures (Table 1). Significantly greater proportions of respondents living in the interior of the country and in the North or Northeast than of those in the South or Southeast reported male-on-female (22\% and $14 \%$ vs. $11 \%$ ) and mutual hitting (17\% and $14 \%$ vs. $8 \%$ ); a greater proportion of respondents living in the North than of those in the South reported female-on-male hitting ( $4 \%$ vs. 3\%). Similarly, male-on-female hitting was more common in rural areas than in urban areas (21\% vs. $14 \%$ ).

As anticipated, male-on-female hitting increased with relationship duration: Eleven percent of respondents in relationships of five years or less reported hitting, compared with $20-21 \%$ of those in relationships of more than five years. Mutual hitting was most common within relationships of 6-15 years. Surprisingly, the proportion of respondents reporting male-on-female hitting was lower in relationships in which the age difference between the male and female partner was three or more years than in relationships in which the age difference was two or fewer years (15\% vs. 21\%).

Financial factors also appear to be important. When the proportion of women experiencing male-on-female hitting was added to the proportion involved in mutual hitting, almost half of women whose partner was of low status had ever been hit, compared with about a quarter of women whose partner was of high status. In addition, the proportion of women who reported hitting their partner was higher among those who used alcohol than among those who did not; the proportion of men who had hit their partner was higher among those who had been inebriated in the last year than among those who had not.

Sexual jealousy, from either partner or both, correlated with all three types of hitting. For example, the proportions of respondents reporting male-on-female and mutual hitting were greater in relationships in which both partners had felt jealous (23\% and 30\%, respectively) than in relationships in which neither had ever been jealous (18\% and $11 \%$, respectively). Male-on-female hitting was most common when the female partner had been jealous, whereas mutual and female-on-male hitting was most common when the male partner had been jealous. The proportion of women reporting male-on-female hitting was greater among those who believed that men should lead in sex than of those who disagreed with that statement (19\% vs. 12\%). 


\begin{tabular}{|c|c|c|c|c|c|}
\hline \multirow[t]{2}{*}{ Characteristic } & \multicolumn{3}{|l|}{$\%$} & \multicolumn{2}{|l|}{ Relative risk ratios } \\
\hline & None & Hit & Hit hard & Hit & Hit hard \\
\hline \multicolumn{6}{|l|}{ Women $(\mathrm{N}=1,665)$} \\
\hline Unhappy with life & 11.3 & $28.5^{*}$ & $37.8^{*}$ & $2.00(0.83-4.83)$ & $4.11(1.06-15.93)^{*}, \dagger$ \\
\hline Mental distress & 41.3 & $55.8^{*}$ & $68.1^{*}$ & $1.80(1.13-2.84)^{*}$ & $3.10(2.25-4.27)^{*}, \dagger$ \\
\hline Poor health & 31.6 & 36.2 & $49.1^{*}, \dagger$ & $1.10(0.67-1.80)$ & $2.39(1.10-5.23)^{*}, \dagger$ \\
\hline Sexual dysfunction & 37.2 & 41.9 & 51.8 & $1.17(0.68-2.01)$ & $1.95(1.03-3.67)^{*}$ \\
\hline \multicolumn{6}{|l|}{ Sexual dissatisfaction } \\
\hline Physicalł & 13.2 & 16.7 & $28.1^{*}$ & $1.16(0.52-2.57)$ & $2.99(1.46-6.13)^{*}$ \\
\hline Emotionalł & 8.7 & $16.1^{*}$ & $28.1^{*}$ & $1.60(0.62-4.14)$ & $4.40(2.07-9.33)^{*}$ \\
\hline Kissing absent‡ & 24.0 & 31.2 & 38.5 & $1.30(0.82-2.06)$ & $3.10(1.20-8.04)^{*}$ \\
\hline Intimacy in sex absent $\neq$ & 42.2 & $51.6^{*}$ & $68.0^{*}, \dagger$ & $1.51(0.86-2.63)$ & $3.46(2.21-5.39)^{*}, \dagger$ \\
\hline \multicolumn{6}{|l|}{ Unwanted sexual behavior } \\
\hline Sex & 22.1 & $30.0^{*}$ & 41.4 & $1.62(1.15-2.30)^{*}$ & $2.60(1.04-6.52)^{*}$ \\
\hline Act during sexł & 19.0 & $31.9^{*}$ & $37.7^{*}$ & $2.18(1.35-3.51)^{*}$ & $2.60(1.32-5.13)^{*}$ \\
\hline Partner's extramarital sex & 8.8 & 10.8 & $36.2^{*}, \dagger$ & $1.43(0.95-2.15)$ & $6.70(1.85-24.22)^{*}, \dagger$ \\
\hline \multicolumn{6}{|l|}{ Recent genitourinary } \\
\hline symptoms & 40.6 & $50.4^{*}$ & $54.5^{*}$ & $1.54(1.12-2.12)^{*}$ & $1.67(1.19-2.33)^{*}$ \\
\hline Ever had an STI & 1.1 & 0.3 & $3.5^{*}, \dagger$ & $0.39(0.10-1.53)$ & $4.20(0.89-19.89)+$ \\
\hline Positive chlamydia test & 3.3 & $1.0^{*}$ & $1.0^{*}$ & $0.38(0.15-0.95)^{*}$ & $0.34(0.13-0.88)^{*}$ \\
\hline Lack of AIDS knowledge & 54.3 & 53.4 & $37.5^{*}, \dagger$ & $0.70(0.50-0.99)^{*}$ & $0.42(0.31-0.57)^{*}, \dagger$ \\
\hline \multicolumn{6}{|l|}{ Men $(\mathrm{N}=1,658)$} \\
\hline Unhappy with life & 10.4 & 12.4 & $34.8^{*}$ & $0.93(0.65-1.35)$ & $5.68(2.42-13.30) * \dagger$ \\
\hline Mental distress & 50.7 & 54.0 & $73.6^{*}$ & $1.16(0.55-2.42)$ & $2.36(1.12-4.96)^{*}$ \\
\hline Poor health & 30.5 & 41.8 & $55.1^{*}$ & $1.71(0.67-4.32)$ & $3.62(1.73-7.57)^{*}$ \\
\hline Sexual dysfunction & 31.5 & 36.6 & 45.0 & $1.12(0.62-2.03)$ & $2.53(0.92-6.92)$ \\
\hline \multicolumn{6}{|l|}{ Sexual dissatisfaction } \\
\hline Physical‡ & 9.0 & $19.7^{*}$ & 17.8 & $2.29(1.01-5.19)^{*}$ & $2.45(0.60-9.95)$ \\
\hline Emotional\# & 6.0 & $21.1^{*}$ & $23.9^{*}$ & $3.87(2.46-6.08)^{*}$ & $4.90(2.31-10.39)^{*}$ \\
\hline Kissing absentł & 16.6 & 15.6 & 8.0 & $0.73(0.18-3.01)$ & $0.76(0.19-3.00)$ \\
\hline Intimacy in sex absent $¥$ & 62.1 & 67.8 & 65.3 & $1.25(0.66-2.38)$ & $1.38(0.62-3.07)$ \\
\hline \multicolumn{6}{|l|}{ Unwanted sexual behavior } \\
\hline Sex & 6.9 & 17.1 & 7.2 & $2.90(0.76-11.00)$ & $0.97(0.26-3.65)$ \\
\hline Act during sex $\neq$ & 10.0 & $26.4^{*}$ & 11.0 & $3.19(1.84-5.52)^{*}$ & $1.11(0.47-2.61)$ \\
\hline Partner's extramarital sex & 7.7 & 18.9 & $35.0^{*}, \dagger$ & $3.05(1.06-8.75)^{*}$ & $6.59(2.52-17.22)^{*}, \dagger$ \\
\hline Recent genitourinary & 178 & 165 & $385^{*}+$ & $0.90(047-173)$ & $274(129-580) *+$ \\
\hline Ever had an STI & $\begin{array}{r}1.0 \\
3.0\end{array}$ & 6.3 & $\begin{array}{l}2.5,1 \\
13.9\end{array}$ & $2.38(0.35-16.24)$ & $4.85(1.25-18.75)^{*}$ \\
\hline Positive chlamydia test & 1.9 & 3.3 & 1.1 & $1.84(0.09-37.32)$ & $0.38(0.03-5.80)$ \\
\hline Lack of AIDS knowledge & 44.0 & 47.8 & 33.9 & $1.15(0.73-1.81)$ & $0.66(0.13-3.30)$ \\
\hline
\end{tabular}

*Significantly different from "none" at $p<.05$. †Significantly different from "hit" at $p<.05$. ‡Among sexually active respondents (1,554 women and 1,590 men). Note: All multivariate equations included 10-year age-group, urban residence and geographic region; some equations included additional measures—see text for details.

In multivariate analyses in which absence of hitting was the outcome reference category, certain variables were associated with all three types of hitting. Compared with those who lived in the South or Southeast coast, respondents who lived in the interior of the country had significantly greater risks of male-on-female and mutual hitting (risk ratios, 2.6 and 3.4), and those in the North or Northeast had greater risks of mutual hitting and female-on-male violence (2.2 and 2.5). In addition, the risks of all types of hitting were elevated among those reporting the female partner had been sexually jealous of the male (4.2-6.1); male jealousy of the female was associated with increased risks of mutual and female-on-male hitting (6.5 and 5.7, respectively), whereas jealousy in both partners was associated with male-onfemale and mutual hitting (3.5 and 6.3).

Other measures were associated with only certain types of partner violence. Male-on-female hitting (as opposed to no hitting) was positively associated with relationships of
6-15 years, the male partner being of low or middle socioeconomic status, the female's financial contribution being $30 \%$ or less of household income, female alcohol consumption and male inebriation (1.6-3.7); it was negatively associated with the male partner being three or more years older than the female (0.7). Female-on-male hitting (as opposed to no hitting) was positively associated with use of alcohol by the female partner (2.9) and negatively associated with the female's financial contribution being more than $45 \%$ of the household income (0.3) and with women believing that men should lead during sex (0.2); mutual hitting was associated with relationships of 6-15 years (2.1) and the male partner being of low socioeconomic status (4.2).

When we conducted logistic regression analyses on hitting without controlling for sexual jealousy, the effect of the other variables on hitting changed only slightly, and the overall pattern was similar to what we found when sexual jealousy was included (not shown). This suggests that in the full set of results, jealousy is not mediating, and therefore obscuring, the effects of other factors, such as the woman's contribution to income.

\section{Adverse Health Outcomes}

In other analyses, we investigated whether certain negative outcomes were associated with intimate partner violence. The prevalence of many of the negative outcomes studied was significantly greater among women who had ever been hit than among those who had never experienced partner violence, and even greater among those who had ever been hit hard (Table 2). For example, 11\% of women who had never been hit reported feeling unhappy with life, compared with $29 \%$ of those who had been hit and $38 \%$ of those who had been hit hard. Exceptions included having a history of STI, testing positive for chlamydia and having a lack of AIDS knowledge. Among men, the prevalence of three outcomes were greater among those who reported hitting than among those who did not, and six were greater among those who reported hard hitting.

In multivariate analyses limited to women, having ever been hit was associated with increased risks of mental distress, having had unwanted sex, having participated in an unwanted act during sex and having had recent genitourinary symptoms (risk ratios, 1.5-2.2); it was associated with decreased risks of testing positive for chlamydia (0.4) and lacking AIDS knowledge (0.7). Having ever been hit hard was associated with increased risks of experiencing almost every adverse health outcome (1.7-6.7); however, severe hitting of women was linked to reduced risks of testing positive for chlamydia (0.3) and lacking AIDS knowledge (0.4).

For men, having been hit was associated with increased risks of feeling physical or emotional dissatisfaction with sex, having participated in an unwanted act during sex and believing that their partner had had extramarital sex (2.3-3.9). Hard hitting was linked with seven out of the 15 possible adverse outcomes, including being unhappy with life, feeling mental distress, having poor health, feeling emo- 
tional dissatisfaction with sex, partner's extramarital sex, recent genitourinary symptoms and ever having had an STI (2.4-6.6).

\section{DISCUSSION}

This study presents the first national estimates of partner hitting in China, using data from a population-based probability sample. Among the sample of adults aged 20-64, one-third of women and nearly one-fifth of men had ever been hit by their current partner. A greater proportion of women than of men had experienced partner violence, as seen in both the direction and severity of reported hitting: Nineteen percent of respondents reported only male-onfemale hitting, compared with 3\% who reported only female-on-male violence. In addition, a greater proportion of women than of men had ever been hit sufficiently hard to cause cuts, bruises or other injuries.

Given the wide variability in sampling procedures, interview conditions and question wording, any comparison to other societies is fraught with difficulties. To begin with, age ranges and the gender of the respondent vary. In 23 of the 28 national studies on partner violence, the sample consisted of women no older than 44 or 49 . If we make our sample more comparable by limiting it to female respondents no older than 49, 33\% report any hitting and 14\% report severe hitting. Compared with findings from other countries, the proportion of Chinese women reporting any hitting is high and the proportion of severe hitting is about average.

Many risk factors for partner violence in China are similar to those in other countries. Like women in other countries, Chinese women are at increased risk of partner violence when their male partner is of low socioeconomic status and when either partner uses alcohol. ${ }^{18}$ The presence of only a modest relationship between women's income share and hitting is also a common finding. ${ }^{19}$

Another finding consistent with what is at least asserted (although often not shown) in the existing literature is the link between patriarchal beliefs and hitting. ${ }^{20}$ Acceptance of the belief that "men should lead in sex and women should follow" is at best an imperfect measure of only one set of possible patriarchal values. Nevertheless, this belief is associated with increased male-on-female and reduced female-on-male hitting.

Several other patterns in the data are less consistent with the existing literature. In U.S. studies, men report less maleon-female hitting than women, possibly because of legal and social disapproval. ${ }^{21}$ In contrast, our findings suggest that Chinese women may underreport male-on-female hitting. This is consistent with the victim being more socially stigmatized than the offender-a pattern that may result when social and legal disapproval of partner violence has yet to be normalized in society and when men and women continue to accept the premise that women should be hit when they displease their partner. ${ }^{22}$ In addition, our data suggest that women's bargaining position has some relationship to whether they have ever been hit: In the multi- variate results for male-on-female hitting, women are most at risk when they contribute only a small share of the couple's income. This is a noteworthy finding that is not always easily demonstrated in the literature. ${ }^{23}$

Another finding inconsistent with previous research is the complexity of links between jealousy and hitting. Some previous research suggests that jealousy and hitting are learned at a young age by males in cultures that believe men should control women. ${ }^{24}$ A second line of interpretation is that jealousy and the attempt to control one's partner are not learned but instinctual. ${ }^{25}$ In contrast to the first theory, we find that Chinese women are just as likely as Chinese men to be jealous. Moreover, jealousy provokes lashing out by both genders-although male-on-female violence is more common and more physically damaging. ${ }^{26}$

What is unanticipated in both theories is that it is often not one's own jealousy that ignites partner violence. Rather, violence tends to be one partner's reaction to the other's jealousy (and, probably, nagging). For example, the odds of male-on-female hitting are significantly increased when the female partner is jealous but not when the male partner is jealous, and the odds of female-on-male hitting are greater when the male is jealous than when the female is jealous. In short, the theory that jealousy and hitting are part of the same control syndrome is not sufficient. Jealousy may be centrally involved, but the jealous partner is usually not the one who becomes violent.

A final set of concerns is whether hitting is associated with negative outcomes among women (and possibly among men as well). The Chinese data are limited in at least two respects. The diagnosis of chlamydia among participants was based on a laboratory test of a urine sample, and although respondents were instructed to report only STIs that had been diagnosed by a doctor, we cannot guarantee that they followed the instructions. All other measures are based on self-reports unsupported by laboratory tests or a documented clinician's diagnosis, thereby introducing unknown error into the results. Second, because this was not a longitudinal study, the data provide evidence for associations but not for causality. Nevertheless, our findings provide at least circumstantial evidence of correlations between past hitting and current health conditions in ways that justify further work in this area.

Chinese women and men who had been hit hard were more likely than those who had not been hit to be unhappy with their life, to be in poor health and to feel mental distress. In addition, female victims reported a variety of other negative correlates, including sexual dysfunction, sexual dissatisfaction, absence of kissing or intimacy during sex, unwanted sex during the relationship and unwanted sexual acts during the previous year. These reports are consistent with sex being induced by a male control syndromeof which hitting is a part. And although males have some of the same patterns, the much more consistent pattern for females suggests that it is male control of females that is the more common problem.

The STI-related aspects of sexual health do not have a 
consistent relationship to spousal hitting. Hitting, particularly severe hitting, was associated with partner's extramarital sex, recent genitourinary symptoms and (among men) ever having had an STI. However, testing positive for chlamydia and having a lack of AIDS knowledge were either statistically unrelated (among men) or associated with an absence of hitting (among women).

\section{CONCLUSIONS}

Intimate partner dynamics in China are similar to those in the rest of the world, adding one more populous society to the list of places where intimate partner violence is a public health issue. For both men and women, our findings suggest that sexual jealousy is an underappreciated and complex risk factor for partner violence. Also, as in other societies, patriarchal values, women's lack of financial autonomy, low male socioeconomic status and alcohol consumption are associated with partner violence. Moreover, our data provide some evidence that hitting is correlated with negative health outcomes-including sexual dysfunction and unwanted and unsatisfying sex-and that these problems particularly affect women.

\section{REFERENCES}

1. Heise LL, Ellsberg M and Gottemoeller M, Ending violence against women, Population Reports, 1999, Series L, No. 11; Jewkes R, Intimate partner violence: causes and prevention, Lancet, 2002, 359(9315):14231429; Krug EG, World Report on Violence and Health, Geneva: World Health Organization (WHO), 2002; Summers RW and Hoffman AM, Domestic Violence: A Global View, Westport, CT, USA: Greenwood Press, 2002; and Kishor S and Johnson M, Profiling Domestic Violence: A MultiCountry Study, Calverton, MD, USA: Macro International, 2004

2. Heise LL, Ellsberg M and Gottemoeller M, 1999, op. cit. (see reference 1); Krug EG, 2002, op. cit. (see reference 1); Centro de Estudios de Población Desarrollo Social (CEPAR), Encuesta Demográfica y de Salud Materna e Infantil, Quito, Ecuador: CEPAR, 2001; Centro Paraguayo de Estudios de Población (CEPEP), Encuesta Nacional de Salud Materna Infantil: 1998, Asunción, Paraguay: CEPEP, 1999; Instituto Nacional de Estadísticas y Censos (INEC), Encuesta Nicaragüense de Demografía y Salud 1998, Managua, Nicaragua: INEC, 1999; Kiev International Institute of Sociology (KIIS), 1999 Ukraine Reproductive Health Survey: Final Report, Kiev, Ukraine: KIIS, 2001; Ministère de la Santé Publique et de la Population (MSPP), Enquête Mortalité, Morbidité et Utilisation des Services, Pétion-ville, Haïti: MSPP, 2000; National Institute of Statistics (NIS), Cambodia Demographic and Health Survey 2000, Phnom Penh, Cambodia: NIS, 2001; Asociación Probienestar de la Familia Colombiana (PROFAMILIA), Resultados Encuesta Nacional de Demografía y Salud 2000, Santafé de Bogotá, Colombia: PROFAMILIA, 2000; and Kishor S and Johnson M, 2004, op. cit. (see reference 1).

3. Heise LL, Ellsberg M and Gottemoeller M, 1999, op. cit. (see reference 1); Jewkes R, 2002, op. cit. (see reference 1); Krug EG, 2002, op. cit. (see reference 1); Summers RW and Hoffman AM, 2002, op. cit. (see reference 1); and Kishor S and Johnson M, 2004, op. cit. (see reference 1).

4. Heise LL, Ellsberg M and Gottemoeller M, 1999, op. cit. (see reference 1); Krug EG, 2002, op. cit. (see reference 1); Campbell JC, Health consequences of intimate partner violence, Lancet, 2002, 359(9314): 1331-1336; Miller JL and Knudsen DD, Family abuse and violence, in: Sussman M, Steinmetz SK and Peterson GW, eds., Handbook of Marriage and the Family, second ed., New York: Plenum Press, 1999, pp. 705-741; Tjaden PG and Thoennes N, Prevalence and consequences of male-tofemale and female-to-male intimate partner violence as measured by the National Violence Against Women Survey, Violence Against Women, 2000, 6(2):142-161; Zierler S, Witbeck B and Mayer K, Sexual violence against women living with or at risk of HIV infection, American Journal of Preventive Medicine, 1996, 12(5):304-310; WHO, Violence Against Women and HIV/AIDS: Setting the Research Agenda, Geneva: WHO, 2000; and Kristner U, Gender-Based Violence and HIV/AIDS in South Africa: A Literature Review, Johannesburg, South Africa: Centre for AIDS Development, Research and Evaluation, 2003.

5. Heise LL, Ellsberg M and Gottemoeller M, 1999, op. cit. (see reference 1); Jewkes R, 2002, op. cit. (see reference 1); Krug EG, 2002, op. cit. (see reference 1); Summers RW and Hoffman AM, 2002, op. cit. (see reference 1); and Kishor S and Johnson M, 2004, op. cit. (see reference 1$)$.

6. Heise LL, Ellsberg M and Gottemoeller M, 1999, op. cit. (see reference 1); Krug EG, 2002, op. cit. (see reference 1); Campbell JC, 2002, op. cit. (see reference 4); Miller JL and Knudsen DD, 1999, op. cit. (see reference 4); Tjaden PG and Thoennes N, 2000, op. cit. (see reference 4); Zierler S, Witbeck B and Mayer K, 1996, op. cit. (see reference 4); WHO, 2000, op. cit. (see reference 4); and Kristner U, 2003, op. cit. (see reference 4).

7. Liu M and Chan C, Enduring violence and staying in marriage: stories of battered women in rural China, Violence Against Women, 1999, 5(12):1469-1492; Xü X, The prevalence and determination of wife abuse in urban China, Journal of Comparative Family Studies, 1997, 28(3):280303; Tang CSK, Wife abuse in Hong Kong Chinese families: a community survey, Journal of Family Violence, 1999, 14(2):173-191; Tang CSK, Marital power and aggression in a community sample of Hong Kong Chinese families, Journal of Interpersonal Violence, 1999, 14(6):586-602; Tang CSK, Wong D and Cheung FMC, Social construction of women as legitimate victims of violence in Chinese societies, Violence Against Women, 2002, 8(8):968-996; Wang X, Why are Beijing women beaten by their husbands? a case analysis of family violence in Beijing, Violence Against Women, 1999, 5(12):1493-1504; Shen C, Yang S and Li D, The Urban and Rural Families at the Millennium, Beijing: China Social Science Press, 1999 (in Chinese); and Institute of Population Studies, Sampling Survey Data of Women's Status in Contemporary China, Beijing: International Academic Publishers, 1994.

8. Levy PS and Lemeshow S, Sampling of Populations: Methods and Applications, third ed., New York: Wiley, 1999; and Parish WL et al., Population-based study of chlamydial infection in China: a hidden epidemic, Journal of the American Medical Association, 2003, 289(10):12651273

9. Dobash RE and Dobash RP, Violence Against Wives: A Case Against Patriarchy, New York: Free Press, 1979; and Buss D, The Dangerous Passion: Why Jealousy Is as Necessary as Love and Sex, New York: Free Press, 2000

10. Dobash RE and Dobash RP, 1979, op. cit. (see reference 9).

11. Anderson K, Gender, status, and domestic violence: an integration of feminist and family violence approaches, Journal of Marriage and the Family, 1997, 59(3):655-669; Macmillan R and Gartner R, When she brings home the bacon: labor-force participation and the risk of spousal violence against women, Journal of Marriage and the Family, 1999 , 61(4):947-958; and Fox GL et al., Economic distress and intimate violence: testing family stress and resources theories, Journal of Marriage and the Family, 2002, 64(3):793-807.

12. Strauss M, Gelles R and Steinmetz S, Behind Closed Doors: Violence in the American Family, Garden City, NY, USA: Anchor, 1980.

13. Ibid.; and Fox GL et al., 2002, op. cit. (see reference 11).

14. Jewkes R, 2002, op. cit. (see reference 1); and Tjaden PG et al., Extent, Nature, and Consequences of Intimate Partner Violence, Washington, DC: U.S. Department of Justice, Office of Justice Programs, National Institute of Justice, 2000

15. Strauss M, Gelles R and Steinmetz S, 1980, op. cit. (see reference 12).

16. Caetano R et al., Agreement on reports of intimate partner violence among white, black, and Hispanic couples in the United States, Journal of Interpersonal Violence, 2002, 17(12):1308-1322; and Schafer J, Caetano $\mathrm{R}$ and Clark CL, Agreement about violence in U.S. couples, Journal of Interpersonal Violence, 2002, 17(4):457-470.

17. Skinner C, Holt D and Smith T, Analysis of Complex Surveys, New York: Wiley, 1989

18. Heise LL, Ellsberg M and Gottemoeller M, 1999, op. cit. (see reference 1); Jewkes R, 2002, op. cit. (see reference 1); Krug EG, 2002, op. cit. (see reference 1); Tjaden PG et al., 2000, op. cit. (see reference 14); and Ellsberg MC et al., Wife abuse among women of childbearing age in Nicaragua, American Journal of Public Health, 1999, 89(2):241-243. 
19. Mason $\mathrm{KO}$, The status of women: conceptual and methodological issues in demographic studies, Sociological Forum, 1986, 1(2):284-300.

20. Tjaden PG et al., 2000, op. cit. (see reference 14); and Dobash RE and Dobash RP, 1979, op. cit. (see reference 9).

21. Caetano R et al., 2002, op. cit. (see reference 16); Schafer J, Caetano R and Clark CL, 2002, op. cit. (see reference 16); and Anderson K, 1997, op. cit. (see reference 11).

22. Krug EG, 2002, op. cit. (see reference 1); and Koenig MA et al., Domestic violence in rural Uganda: evidence from a community-based study, Bulletin of the World Health Organization, 2003, 81(1):53-81.

23. Mason KO, 1986, op. cit. (see reference 19).

24. Dobash RE and Dobash RP, 1979, op. cit. (see reference 9).

25. Buss D, 2000, op. cit. (see reference 9).

26. Ibid

\section{RESUMEN}

Contexto: La violencia contra la pareja intima se ha estudiado en muchos países desarrollados y en desarrollo; China permanece siendo una de las pocas sociedades populosas de la cual no se conoce el nivel de prevalencia y los determinantes de la violencia contra la pareja íntima.

Métodos: Los datos de una muestra representativa a nivel nacional de mujeres y hombres de 20-64 años, casados o con una pareja constante, ofrecen unas estimaciones de los casos de violencia contra la pareja íntima en China. Se utilizaron análisis de regresión logística binominal y multinominal, ajustados por el diseño de la muestra, para examinar los factores de riesgo y los resultados negativos que están relacionados con la violencia contra la pareja.

Resultados: En conjunto, el 34\% de las mujeres y el 18\% de los hombres habian sido blanco de golpes durante su relación actual; la prevalencia de golpes que resultaban en sangrados, contusiones, hinchazones o dolor y heridas severas era el 12\% de las mujeres y el 5\% de los hombres. Entre los factores de riesgo significativos de la violencia intrafamiliar se incluían los celos, las creencias patriarcales, los bajos ingresos aportados por la mujer al hogar, la condición socioeconómica baja del hombre, el consumo del alcohol, y la residencia en regiones que no fueran el sur o el sudeste del país. Los golpes severos constituyeron un factor de riesgo significativo para la notificación individual de problemas de salud general y sexual, incluida la disfunción sexual, insatisfacción sexual y sexo no deseado.
Conclusiones: Al igual que en otras sociedades, la violencia contra la pareja intima en China es común y está relacionada con resultados adversos en la salud general y sexual.

\section{RÉSUMÉ}

Contexte: La violence par un partenaire intime a fait l'objet d'études dans de nombreux pays industrialisés et en développement. La Chine demeure l'une des rares grandes sociétés où la prévalence et les corrélations de ce type de violence restent inconnues. Méthodes: Les données d'un échantillon nationalement représentatif des femmes et hommes de 20 à 64 ans mariés ou en relation stable permettent d'estimer la violence par un partenaire intime en Chine. Les facteurs de risque et les issues négatives associées à la violence par un partenaire sont examinés par analyses de régression binomiale et multinomiale corrigées en fonction du plan d'échantillonnage.

Résultats: Dans l'ensemble, 34\% des femmes et 18\% des hommes avaient jamais été battus dans le contexte de leur relation au moment de l'enquête; la prévalence des coups donnant lieu à saignements, ecchymoses, tuméfactions ou douleurs et blessures graves était de $12 \%$ pour les femmes et de $5 \%$ pour les hommes. Les facteurs de risque significatifs de violence par un partenaire se sont révélés être la jalousie sexuelle, les croyances patriarcales, la faible contribution de la femme au revenu du ménage, le faible rang socioéconomique de l'homme, la consommation d'alcool et la résidence dans les régions autres que le Sud et le Sud-Est. Le frappement grave s'est avéré un facteur de risque significatif d'issues de santé générale et sexuelle négatives auto-déclarées (dysfonctionnement sexuel, insatisfaction sexuelle et rapports sexuels non désirés).

Conclusions: Comme dans d'autres sociétés, la violence par un partenaire intime en Chine est courante et associée à des issues de santé générale et sexuelle indésirables.

\section{Acknowledgments}

Primary support for this research was provided by the National Institute of Child Health and Human Development grant RO1 HD34157. Additional support was provided by the University of Chicago/NICHD Population Research Center (P30 HD18288) and University of North Carolina/NIH Fogarty Center (P30 AI50410).

Author contact:w-parish@uchicago.edu 